\title{
三谷管雄 学位論文審査要旨
}

\author{
主 查 岸本 拓 治 \\ 副主查萩 野浩 \\ 同黒 沢 洋一
}

\section{主論文}

Risk factors for second hip fractures among elderly patients

（高齢者における大腿骨近位部骨折再発の危険因子）

(著者: 三谷管雄、清水正人、安保雅博、萩野浩、黒沢洋一)

平成22年 Journal of Orthopaedic Science 掲載予定 


\section{学 位 論 文 要 旨}

\section{Risk factors for second hip fractures among elderly patients （高齢者における大腿骨近位部骨折再発の危険因子）}

本邦の急速な高齢化に伴い、高齢者の転倒による大腿骨近位部骨折は増加傾向にある。 さらに、大腿骨近位部骨折に引き続き起こる再骨折の増加も懸念されている。しかし、大 腿骨近位部再骨折の危険因子についての研究は未だ少ない。そのため、後ろ向きコホート 研究により高齢者の大腿骨近位部再骨折に関連する危険因子を分析した。

\section{方 法}

2001年1月から2007年12月の間に転倒による大腿骨近位部骨折を受傷して鳥取県中部の 整形外科病院を受診した 400 人の患者のうち、骨折後 1 年以内に死亡した 11 人と 50 歳未満の 5 人の計 16 人を除いた 384 人（女性 320 人、男性 64 人）を研究対象とした。全対象者の初回骨 折時の平均年齢は83. $1 \pm 9.0$ 歳（51〜102歳）であった。

これらの対象の性別、年齢、体格指数 (BMI)、臥床期間、リハビリ期間、退院先（自宅か 施設か）、合併症を診療録から調査（再骨折患者は初回骨折時の情報）した。対象とした 合併症は、脳神経疾患（脳出血、脳梗塞、パーキンソン病）、糖尿病、高血圧、心疾患（心 筋梗塞、狭心症、心不全、不整脈）、呼吸器疾患（慢性閉塞性肺疾患、喘息、肺炎、慢性 呼吸不全）、骨・関節疾患、認知症であった。また、2007年12月までの観察期間中の対象 者の再骨折の有無は、外来でのfollow-upに加えて、患者家族、患者入居施設スタッフ、ケ アマネージャーへ問い合わせて調べた。再骨折の有無により対象者を再骨折（両側骨折） 群と対照（片側骨折）群に分け、調査した因子を両群で比較し、危険因子を抽出した。さ らに、多変量解析としてCox比例ハザードモデルを適応し、再骨折の危険因子のハザード比 を算出した。統計学的処理にはSPSSを使用した。

\section{結 果}

研究対象 384 人の観察期間は合計 1140.0 人・年で、平均 $3.0 \pm 1.4$ 人・年であった。この期 間中に 49 人の再骨折患者があり、発生率は 43 人/千人・年で、 $85.7 \%$ （42人）は初回骨折よ り3年以内に起こっていた。統計学的有意差は認められなかったが、初回骨折の年齢が再骨 折群85.1 1 7. 9歳（対照群：82.8 19.1 歳）で高い傾向が示された。性、体格指数、臥床期 
間、リハビリ期間、退院先についての群間比較では統計学的有意差は認められなかった。 再骨折の有無と合併症の有病率では呼吸器疾患で再骨折群が $30.6 \%$ 、対照群で $7.2 \%$ 、認知症 で再骨折群が $61.2 \%$ 対照群で $43.9 \%$ と有意差が認められた $\left(x^{2}\right.$ 検定 $\left.\mathrm{P}<0.05\right)$ 。呼吸器疾患と認 知症を性、年齢で調整したCox比例ハザードモデルを用いた分析では、認知症 (ハザード比 1. 87：[95\%信頼区間 1.02-3.41 P=0.042]) と呼吸器疾患 (ハザード比:4.41[95\%信頼区間 2.33-8.34 $\mathrm{P}<0.001])$ が再骨折に有意に関連していた。

\section{考 察}

今回の研究では、大腿骨近位部骨折に引き続き起こる再骨折の発生率は 43 人/千人・年で あった。Yamanashiらの研究では29人/千人・年で、今回の結果はこれより高い発症率とな った。これは、本研究では平均年齢が高く、観察期間が長いことが影響していたと推測さ れる。また、再骨折の $85 \%$ は年以内に起こっており、先行研究と同様の結果であった。

認知症の合併は大腿骨近位部骨折の再骨折の危険性を高めることが、先行研究と同様に 本研究でも示されたが、新たな知見として呼吸器疾患が危険因子として示された。先行研 究においても呼吸器疾患と再骨折の関連は疑われていたが、有意な関連はみられなかった。 本研究は、先行研究に比較して対象者の年齢が高いため、呼吸器疾患の有病率が高くなり、 有意な関連がみられたと推測される。

以上より、初回骨折で認知症または呼吸器疾患の合併症を有する高齢患者に対し、再骨 折の予防策を重点的に提供する必要があると考えられる。

\section{結 論}

大腿骨近位部再骨折の危険因子を調査した。調査期間での発生率は 43 人/千人・年で、再 骨折患者の $85.7 \%$ が初回骨折の 3 年以内に受傷していた。大腿骨近位部再骨折の危険因子と して認知症と呼吸器疾患が挙げられた。 